Pak. j. sci. ind. res. Ser. B: biol. sci. 2016 59(3) 164-171

\title{
An Assessment of the Bivalve Perna viridis, as an Indicator of Heavy Metal Contamination in Paradise Point of Karachi, Pakistan
}

\author{
Rashida Qari $^{\mathrm{a} *}$, Olufemi Ajiboye ${ }^{\mathrm{b}}$, Saima Imran ${ }^{\mathrm{a}}$ and Abdul Rahim Afridic \\ anstitute of Marine Science, University of Karachi, Karachi - 75270, Pakistan \\ bNigerian Institute for Oceanography and Marine Research, Sapele Station, PMB 4015, Sapele, \\ Delta State, Nigeria \\ ${ }^{\mathrm{c} C}$ Centre of Excellence in Marine Biology, University of Karachi, Karachi - 75270, Pakistan
}

(received September 3, 2015; revised May 6, 2016; accepted May 12, 2016)

\begin{abstract}
The edible bivalves Perna viridis (green mussel), $(\mathrm{n}=100)$ were analysed for their total $\mathrm{Hg}$, $\mathrm{Pb}, \mathrm{Cu}, \mathrm{Ni}, \mathrm{Zn}, \mathrm{Co}, \mathrm{Fe}, \mathrm{Cr}, \mathrm{Cd}$, and $\mathrm{Mn}$ concentrations to indicate heavy metal contamination in Paradise Point of Karachi coast using atomic absorption spectrophotometer. There are large seasonal variations in the metal concentrations of $\mathrm{Mn}(0.025-0.67 \mu \mathrm{g} / \mathrm{g}), \mathrm{Fe}(0.055-7.740 \mu \mathrm{g} / \mathrm{g}), \mathrm{Ni}(0.004-0.52 \mu \mathrm{g} / \mathrm{g}), \mathrm{Hg}(0.0001$ $0.004 \mu \mathrm{g} / \mathrm{g}), \mathrm{Zn}(0.04-3.32 \mu \mathrm{g} / \mathrm{g}), \mathrm{Cu}(0.008-1.66 \mu \mathrm{g} / \mathrm{g}), \mathrm{Pb}(0.022-2.43 \mu \mathrm{g} / \mathrm{g}), \mathrm{Co}(0.01-0.044 \mu \mathrm{g} / \mathrm{g}), \mathrm{Cd}$ $(0.04-0.88 \mu \mathrm{g} / \mathrm{g})$ and $\mathrm{Cr}(0.13-1.20 \mu \mathrm{g} / \mathrm{g})$ recorded in bodies/soft tissues of $P$. viridis obtained in the samples of the year 1993 and 2012 at the Paradise Point of Karachi coast. The results of heavy metals are in the following descending order of concentration in the samples collected in the year 1993: $\mathrm{Fe}>\mathrm{Cr}>\mathrm{Zn}>\mathrm{Mn}>$ $\mathrm{Pb}>\mathrm{Cd}>\mathrm{Cu}>\mathrm{Ni}>\mathrm{Co}>\mathrm{Hg}$, while $\mathrm{Fe}>\mathrm{Zn}>\mathrm{Pb}>\mathrm{Cu}>\mathrm{Cr}>\mathrm{Cd}>\mathrm{Mn}>\mathrm{Ni}>\mathrm{Co}>\mathrm{Hg}$ order was recorded in samples collected in the year 2012. The high accumulation of metals was found mostly in the samples collected in the year 2012 when compared with the samples of the year 1993. This is an indication that the area under study showed signs of being exposed to significant levels of heavy metal pollution due to direct discharge of industrial and domestic wastes along the coast. The concentrations of these heavy metals were lower than the permissible limits for human consumption. However, if this pollution persists, it can prove to be very detrimental in future.
\end{abstract}

Keywords: Paradise Point, heavy metals, pollutants, industrial wastes, domestic wastes

\section{Introduction}

Marine pollution is a major threat to the health of millions of people, marine animals and plants. The pollution, especially of the metals (either heavy or trace) poses a direct threat to marine life and ultimately the human health (Qari and Siddiqui, 2004). The main sources of pollution in Karachi coastal water includes domestic and industrial waste, tanneries effluents, rainfall and associated pollutant from runoff, shipping and agricultural sources (Qari and Siddiqui, 2008). The rapid industrialisation and urbanisation of the city has altered the quality of the environment and created ecological disturbances and associated problems for the local community (Siddiqui et al., 2009).

Pollution in the Karachi coastal region is mainly attributed to the Lyari and Malir rivers, which are served by various channels of untreated domestic and industrial waste, carrying more than 300 million gallons per day (MGD) $\left(1,125,000 \mathrm{~m}^{3} /\right.$ day) of the untreated effluent of

*Author for correspondence; E-mail: rqari2002@yahoo.com more than 6,000 industries. These rivers ultimately drain into the beaches of the Arabian sea (Hasnie and Qureshi, 2002; Rizvi et al., 1988). It is estimated that about 300 MGD of wastewater is generated in Karachi out of which only $40 \mathrm{MGD}$ is treated, rest of the water waste and the treated effluents are discharged into the sea and creating harm to marine environment (Khattak et al., 2012). Thus, it has become important to estimate the heavy metal concentration in organisms which act as bio-accumulators in sediments, in overlying water, in fresh water, estuarine and marine environment because many of these organisms are indicator of metal contamination. Bio-monitoring by employing living organisms such as mussels, which is an economically important bivalve with outstanding potential as sentinel organism (Qari et al., 2015) and as sensor plays a vital role in governmental and industrial strategies to identify, assess, control, and reduce pollution problems (Krishnakumar et al. 1995; 1994). The intertidal portion of the exposed rocky shore at Paradise Point, the present study site, harbours a large population of $P$. viridis. The present 
investigation provides first-hand basic information about many aspects of bioecology of green mussel ( $P$. viridis) from northern Arabian Sea. The aim of this present study is to determine the levels of contaminants in $P$. viridis from exposed shore of Paradise Point, Karachi coast at low tide and possible health risks to the consumers. The study also examines an increase of metal concentration levels with time in Paradise Point of Karachi coast.

\section{Materials and Methods}

Sampling. The green mussel, $P$. viridis $(\mathrm{n}=100)$ were sampled from exposed shore of Paradise Point, Karachi coast (Fig. 1) at low tide in the year 1993 and 2012 for comparison of the data of two different periods. All the samples collected were carefully cleaned from mud debris and other epiphytes with filtered seawater, in the laboratory. Digestion of dried samples was carried out as described by Denton and Burdon-Jones (1986).

Sample preparation. Perna viridis samples were dried at $70{ }^{\circ} \mathrm{C}$ for $24 \mathrm{~h}$ till a constant weight was achieved. The samples were then homogenised with a porcelain pestle and mortar to a powder form, sieved and stored in plastic bottle until further analysis. Digestion of $P$. viridis samples was carried out as described by Denton and Burdon-Jones (1986). Triplicate samples of $P$. viridis $(1 \mathrm{~g})$ was digested with concentrated nitric acid $(4 \mathrm{~mL})$ and concentrated perchloric acid $(2 \mathrm{~mL})$ in $50 \mathrm{~mL}$ Teflon beaker (prewashed with nitric acid solution) covered with lid at $80{ }^{\circ} \mathrm{C}$ on a hot plate.

Analysis. After digestion and evaporation of acid, metal salts were re-dissolved in metal free deionised water and the final volume was made up to $100 \mathrm{~mL}$ in volumetric flask. Standards were prepared in deionized water from stock standard AA solution (May and Baker Ltd., Dagenham, England). Reagents blank were treated similarly as samples using same volume of acid and deionised water. In digested samples of $P$. viridis, concentrations of $\mathrm{Hg}, \mathrm{Pb}, \mathrm{Cu}, \mathrm{Ni}, \mathrm{Zn}, \mathrm{Co}, \mathrm{Fe}, \mathrm{Cr}, \mathrm{Cd}$ and Mn were measured by Atomic Absorption Spectrophotometer.

\section{Results and Discussion}

There are large seasonal variations in metal concentrations of Mn $(0.025-0.67 \mu \mathrm{g} / \mathrm{g}), \mathrm{Fe}(0.055-7.740 \mu \mathrm{g} / \mathrm{g})$, $\mathrm{Ni}(0.004-0.52 \mu \mathrm{g} / \mathrm{g}), \mathrm{Hg}(0.0001-0.004 \mu \mathrm{g} / \mathrm{g}), \mathrm{Zn}(0.04-$ $3.32 \mu \mathrm{g} / \mathrm{g}), \mathrm{Cu}(0.008-1.66 \mu \mathrm{g} / \mathrm{g}), \mathrm{Pb}(0.022-2.43 \mu \mathrm{g} / \mathrm{g})$, Co (0.01-0.044 $\mu \mathrm{g} / \mathrm{g}), \mathrm{Cd}(0.04-0.88 \mu \mathrm{g} / \mathrm{g})$ and $\mathrm{Cr}(0.13-$ $1.20 \mu \mathrm{g} / \mathrm{g}$ ) recorded in bodies/soft tissues of $P$. viridis collected as samples in the year 1993 and 2012 at the Paradise Point of Karachi coast (Fig. 2-11). The values of $\mathrm{Fe}, \mathrm{Zn}, \mathrm{Cu}, \mathrm{Cd}$ and $\mathrm{Pb}$ concentrations in $P$. viridis collected from the exposed shore of Paradise Point of Karachi coast were compared to permissible limits from established guidelines for food safety (FDA, 2001;

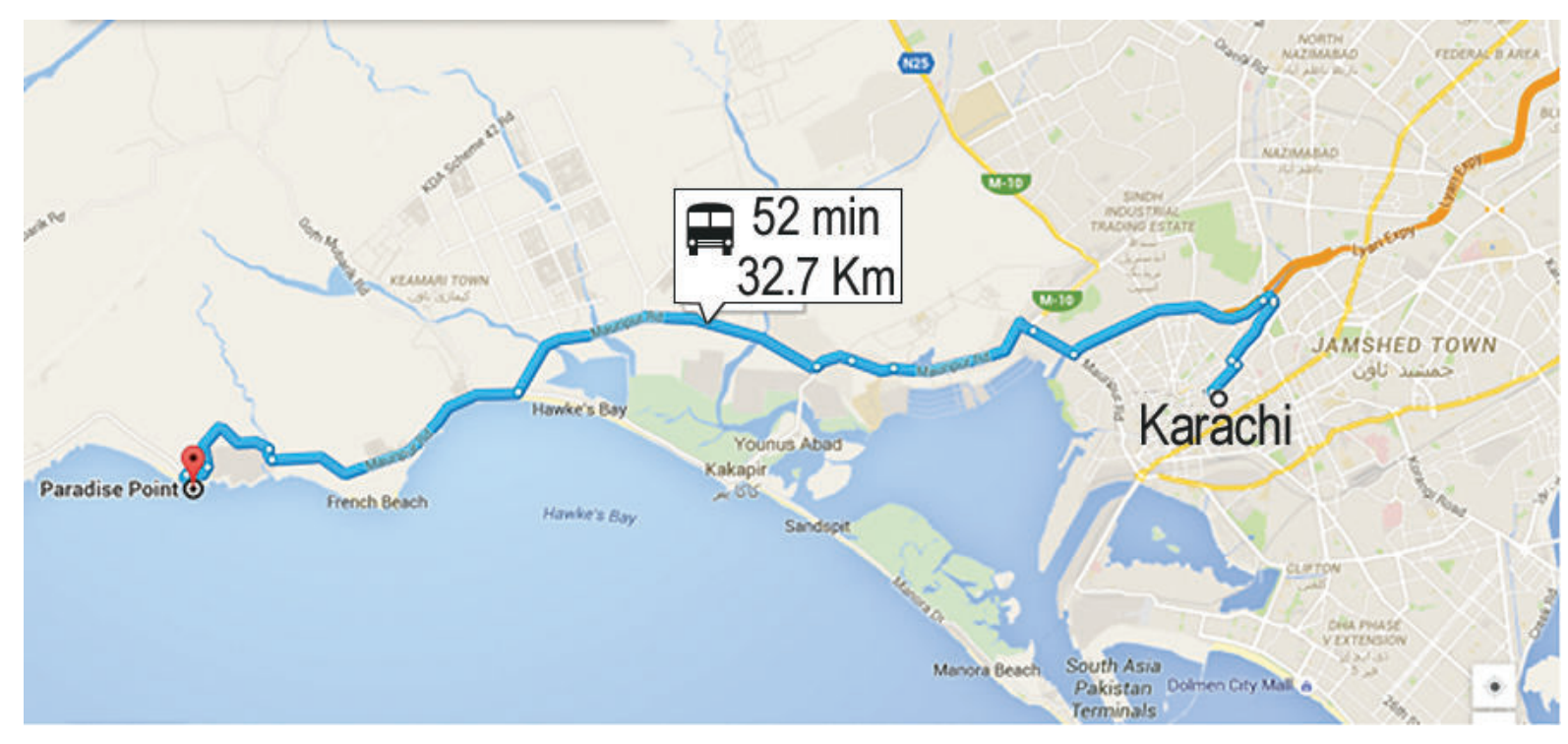

Fig. 1. Map of the Karachi coast showing location of the sampling beach (Paradise Point), source: www. google.com 
WHO, 1982) and maximum permissible limits established by Malaysian Food Regulations (MFR, 1985) (Table 1). The observed concentrations of these metals were within the maximum permissible level (MPL) as shown in Table 1. However, if this pollution persists, it can prove to be very detrimental in future.

All the studied metal levels $(\mathrm{Hg}, \mathrm{Pb}, \mathrm{Cu}, \mathrm{Ni}, \mathrm{Zn}, \mathrm{Co}$, $\mathrm{Fe}, \mathrm{Cr}, \mathrm{Cd}$, and $\mathrm{Mn}$ ) found in the green mussels, $P$. viridis collected from exposed shore of Paradise Point, Karachi coast at low tide in the year 2012 were higher than those detected in mussels collected in 1993. The results are shown in (Fig. 2-11). This is an indication that the area under study showed signs of being exposed to significant levels of heavy metal pollution due to direct discharge of industrial and domestic wastes along the coast. The results of heavy metals concentrations in the following descending order in the samples collected in the year 1993 were $\mathrm{Fe}>\mathrm{Cr}>\mathrm{Zn}>\mathrm{Mn}>\mathrm{Pb}>\mathrm{Cd}>\mathrm{Cu}>\mathrm{Ni}>\mathrm{Co}>\mathrm{Hg}$, while $\mathrm{Fe}>\mathrm{Zn}>\mathrm{Pb}>\mathrm{Cu}>\mathrm{Cr}>\mathrm{Cd}>\mathrm{Mn}>\mathrm{Ni}>\mathrm{Co}>\mathrm{Hg}$ were recorded in samples collected in the year 2012. The results of the present study have therefore, confirmed that the green mussels ( $P$. viridis) have greater capacity for accumulation of metals.

The large seasonal variation recorded in the metal concentrations from the exposed shore of Paradise Point, Karachi coast in the year 1993 and 2012 could be as a result of upwelling on the composition of coastal water. High concentrations of metals also indicate anthropogenic influences (Qari and Siddiqui, 2004). The present ranges of concentration of metals $(\mathrm{Hg}, \mathrm{Pb}, \mathrm{Cu}, \mathrm{Ni}, \mathrm{Zn}$, $\mathrm{Co}, \mathrm{Fe}, \mathrm{Cr}, \mathrm{Cd}$, and $\mathrm{Mn}$ ) were higher when compared with the baseline composition of seawater (Riley and Skirrow, 1975; Horne, 1969). This could be due to the direct discharge of industrial and domestic wastes (along the coast) by Lyari river and the riverborne trace metals. The erosion of the shores at the bottom, diffusion from shelf sediments and deposition of atmospheric particulate also increased the metal concentration levels. Another source of pollution is Karachi atomic nuclear power plant located near the Paradise Point. This heavy water reactor has a generating capacity of 137 megawatt. It uses 0.15 million gallons of seawater per minute for cooling purpose. Chlorine is used for the control of biofouling problems in this plant, which discharge stack of gases in the atmosphere and liquid wastes, radioactive substances, a number of heavy metals and heated water sub-tidally on the nearby rock shore.

The trends of accumulation of heavy metals were also worked out with respect to seasons/months at low tide in the year of 1993 and 2012 for comparison of the data of two different periods. For the present probe, the metal variations are recorded in two seasons i.e., summer (starting from April-September) and winter (from OctoberMarch). The study showed that the concentration levels of most of the metals recorded in the soft tissues of $P$. viridis varied from season to season, year to year and even month to month. The highest concentration of $\mathrm{Mn}$ $(0.67 \mu \mathrm{g} / \mathrm{g})$ was measured in the month of October 2012 and lowest $(0.025 \mu \mathrm{g} / \mathrm{g})$ in the month of May 1993 as shown in (Fig. 2). The maximum concentration of $\mathrm{Fe}$ $(7.740 \mu \mathrm{g} / \mathrm{g})$ was measured in August 2012 and minimum level $(0.055 \mu \mathrm{g} / \mathrm{g})$ in July 1993 as shown in (Fig. 3). The highest Ni concentration $(0.52 \mu \mathrm{g} / \mathrm{g})$ was recorded in August 2012 while the least $(0.004 \mu \mathrm{g} / \mathrm{g})$ was recorded in July 1993 as shown in (Fig. 4). The maximum concentration of $\mathrm{Hg}(0.004 \mu \mathrm{g} / \mathrm{g})$ was measured in February 2012 and the minimum level $(0.0001 \mu \mathrm{g} / \mathrm{g})$ in October 1993 as shown in (Fig. 5). The highest concentration of $\mathrm{Zn}(3.32 \mu \mathrm{g} / \mathrm{g})$ was measured in June 2012 while the least concentration $(0.04 \mu \mathrm{g} / \mathrm{g})$ were observed in May 1993 as shown in (Fig. 6). The maximum concentration of $\mathrm{Cu}(1.66 \mu \mathrm{g} / \mathrm{g})$ was recorded in November 2012 and

Table 1. Comparison of different heavy metals ( $\mathrm{Fe}, \mathrm{Zn}, \mathrm{Cu}, \mathrm{Cd}$ and $\mathrm{Pb}$ ) concentrations in soft tissue of $P$. viridis sampled from Paradise Point of Karachi with other sampling locations from previous studies and International regulation value for food

\begin{tabular}{llllll}
\hline \hline Sampling area & $\mathrm{Cu}$ & $\mathrm{Cd}$ & $\mathrm{Zn}$ & $\mathrm{Pb}$ & $\mathrm{Fe}$ \\
\cline { 2 - 6 } & & & $(\mu \mathrm{g} / \mathrm{g})$ & \\
\hline Present study (Paradise Point, Karachi, Pakistan) & $0.008-1.66$ & $0.04-0.88$ & $0.04-3.32$ & $0.022-2.43$ & $0.055-7.740$ \\
Certified reference material (CRM) & $2.34 \pm 0.16$ & $0.043 \pm 0.008$ & $25.6 \pm 2.3$ & $0.065 \pm 0.007$ & $142 \pm 10$ \\
Maximum permissible levels (MPL) (WHO, 1982) & 10 & 2 & 100 & 5 & - \\
Maximum permissible levels (MPL) (FDA, 2001) & 100 & 0.2 & 150 & 1.5 & - \\
Maximum permissible levels (MPL) (MFR, 1985) & 30 & 1 & 100 & 2 & - \\
\hline \hline
\end{tabular}


the least $(0.008 \mu \mathrm{g} / \mathrm{g})$ in May-July 1993 as shown in (Fig. 7). The highest $\mathrm{Pb}(2.43 \mu \mathrm{g} / \mathrm{g})$ concentration was detected in September 2012 and the lowest $(0.022 \mu \mathrm{g} / \mathrm{g})$ in May 1993 as shown in (Fig. 8). Co and Cd had the highest levels $(0.044 \mu \mathrm{g} / \mathrm{g}, 0.88 \mu \mathrm{g} / \mathrm{g})$ in May and July 2012 , respectively, and lowest $(0.01 \mathrm{mg} / \mathrm{L}, 0.04 \mathrm{mg} / \mathrm{L})$ in January1993 as shown in (Fig. 9) and (Fig. 10). The highest mean of $\mathrm{Cr}(1.20 \mu \mathrm{g} / \mathrm{g})$ was detected in February 2012 and the lowest $(0.13 \mu \mathrm{g} / \mathrm{g})$ in February 1993 as shown in (Fig. 11). Mostly, the high concentration of metals was found in summer and low in winter (Figs. 2-11).

Higher concentrations of heavy metals like $\mathrm{Fe}, \mathrm{Pb}, \mathrm{Zn}$, and $\mathrm{Cu}$ in the green mussel (P. viridis) had been reported by Qari et al. (2015); Ali et al. (2014); Sasikumar et al. (2006); Krishnakumar et al. (1998) and Sankaranarayanan et al. (1976), while Fe accumulation was highest among the metals studied. Similarly, higher concentrations of heavy metals like $\mathrm{Pb}, \mathrm{Cd}, \mathrm{Cr}$ and $\mathrm{Cu}$ were also observed in $P$. viridis as reported by Blackmore and Wang (2003) and Shin et al. (2002). The port and several industries are located in the Karachi city. Untreated or partially treated industrial and domestic waste waters which are discharged directly or carried by several streams into the Karachi coastal water could be attributed to the higher concentrations of heavy metals such as $\mathrm{Fe}, \mathrm{Zn}$, $\mathrm{Pb}, \mathrm{Cd}, \mathrm{Cr}, \mathrm{Cu}$ and other heavy metals recorded in the soft tissues of $P$. viridis in Paradise Point of Karachi. Studies conducted by Qari and Siddiqui (2004) showed that concentrations of $\mathrm{Mn}, \mathrm{Cu}, \mathrm{Zn}, \mathrm{Cr}$ and $\mathrm{Pb}$ and other metals in coastal areas are believed to be elevated due to discharge of considerable quantities of untreated and partially treated domestic and industrial wastes.

The concentration of $\mathrm{Fe}$ was the highest as compared to other heavy metals at low tides in both years i.e., 1993 and 2012 (Fig. 3). It is assumed that high input of metals and other inorganic and organic substances

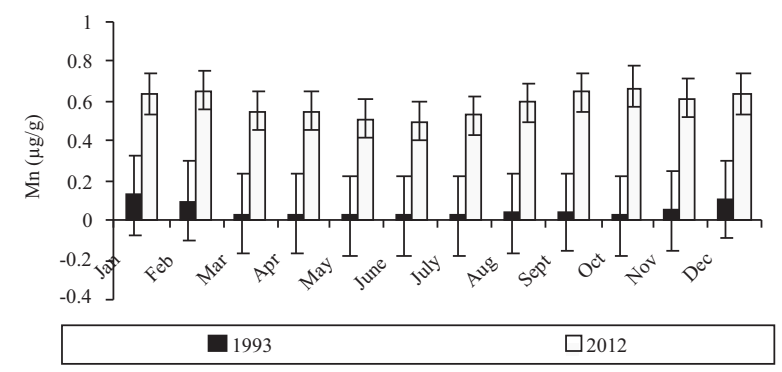

Fig. 2. Mn concentration in P. viridus in two different periods. are coming in the form of industrial and domestic wastes in Paradise Point, Karachi coast. These anthropogenic sources play a major role in increasing the concentration of Fe in Paradise Point, Karachi coast. The main sources of $\mathrm{Fe}$ are mostly from the industries situated in the coastal area. The pollutants from the industries are directly poured into the stream from where it has been mixed with the sea water. The low residence time in oxidizing environment favours the rapid precipitations of iron (Khattak et al., 2012). The observed highest concentration of $\mathrm{Fe}$ in the soft tissue of $P$. viridis in the two periods (1993 and 2012) when compared to other heavy metals detected in the soft tissues of the green mussels was clearly indicating the tendency of organism in accumulating higher concentration of $\mathrm{Fe}$ in soft tissue. This might also be due to the major role played by this essential metal in catalysing various enzymatic activities (Kamaruzzaman et al., 2011).

High concentrations of $\mathrm{Cu}, \mathrm{Zn}, \mathrm{Cr}, \mathrm{Pb}$ and other metals detected in $P$. viridis sampled at the exposed shore of Paradise Point, Karachi coast in the two periods (1993 and 2012) are also due to harbour activities such as dredging and cargo handling, the dumping of ship waste and other coastal activities (Qari and Siddiqui, 2008). It was also reported by Ansari et al. (2001) that the concentration of $\mathrm{Cu}, \mathrm{Ni}, \mathrm{Zn}, \mathrm{Pb}, \mathrm{Cr}$ and $\mathrm{Cd}$ were high in sludge samples of industrial area. Considering these facts, the present study asserted the research findings by those authors (Ansari et al., 2001). According to Qari and Siddiqui (2008), coastal areas with heavy metal pollution needs special attention because continuous pollution inventories will have adverse effect in terms of increase in toxicity levels of the marine food chain, stress on marine plants and animals, adverse effect on the health of inhabitants such as fisher men and bathing tourist. Urgent attention is needed to combat pollution in marine environment of Karachi coast.

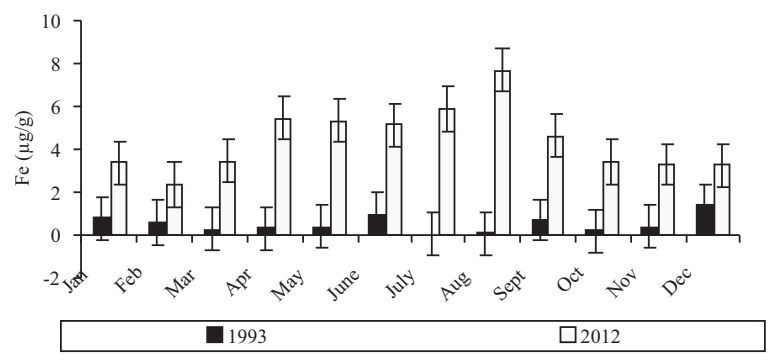

Fig. 3. Fe concentration in P. viridus in two different periods. 
The highest concentration in cadmium (Cd) causes several health problems in human. Cadmium and its compounds along with mercury and some other dangerous metals are, however, included in the blacklist. It is being used routinely in different industrial processes and its potential hazard to life form is predominant. Eating food or drinking water with very high cadmium levels severely irritates the stomach, leading to vomiting and diarrhoea, and sometimes death. Eating lower levels of cadmium over a long period of time can lead to a build-up of cadmium in the kidneys. If it reaches a high enough level in the kidney it will cause kidney damage, and also causes bones to become fragile and break easily. Cadmium $(\mathrm{Cd})$ is widely distributed at low level in the environment and most foods have an inherently low level of $\mathrm{Cd}$ which has been shown to bind to the protein and accumulate significantly in higher level (FDA, 2001). Ololade et al. (2008) reported that $\mathrm{Cd}$ level is almost 10 times higher in shell fishes than in fin fishes. The transport of fertilizer in nearby areas to the estuaries by leaching and erosion as a result of agricultural activities apart from fishing by the village folks could be responsible for the higher level of $\mathrm{Cd}$ in shell fishes than in fin fishes. On the other hand, it has been observed that bivalves do not regulate $\mathrm{Cd}$ in their

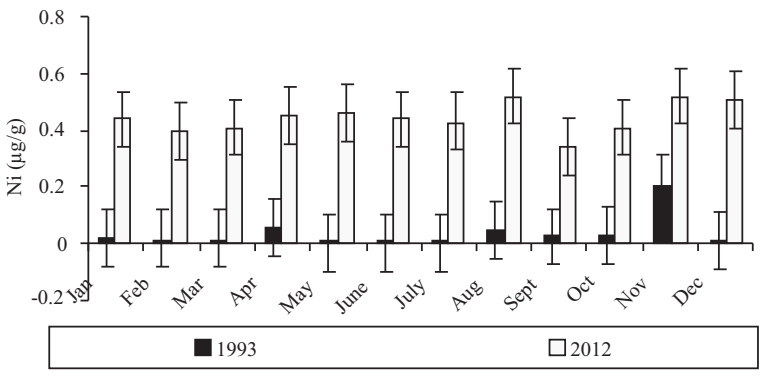

Fig. 4. Ni concentration in P. viridus in two different periods.

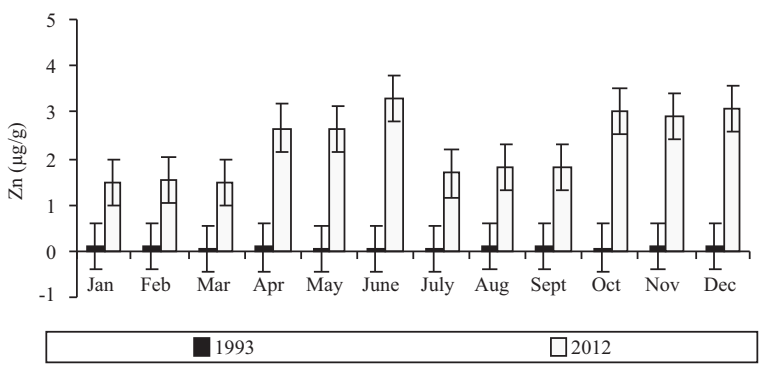

Fig. 6. $\mathrm{Zn}$ concentration in P. viridus in two different periods. body tissues. According to Li et al. (2006), bivalves do not regulate $\mathrm{Cd}$ therefore, accumulate this element in their body. In view of this reason, it is plausible that bivalves such as $P$. viridis might not be able to regulate $\mathrm{Cd}$ in their body.

Mercury $(\mathrm{Hg})$ is one of the heavy metals in the marine ecosystem that are of great concern if present at an elevated level as it could have hazardous impacts due to its toxicity (Yap et al., 2007). Evidence of this concern to public health was given by other researchers reporting on $\mathrm{Hg}$ contamination in the biota related to human beings (Zhou and Wong, 2000; Moraes et al., 1997; Leah et al., 1982). However, the concentration of $\mathrm{Hg}$ was the lowest as compared to other heavy metals analysed in present investigation in the two periods (1993 and 2012). The low concentrations of $\mathrm{Hg}$ detected in the soft tissues of $P$. viridis in the present study, could be due to the fact that metallothionein might play a role in regulating the $\mathrm{Hg}$ excretion as well as storage (Roesijadi, 1980). The lowest Hg levels observed in the present study could also be due to the metal-binding proteins being present at much lower concentrations in $P$. viridis body tissues. The observed low concentration of $\mathrm{Hg}$ in the soft tissue of the organism was clearly

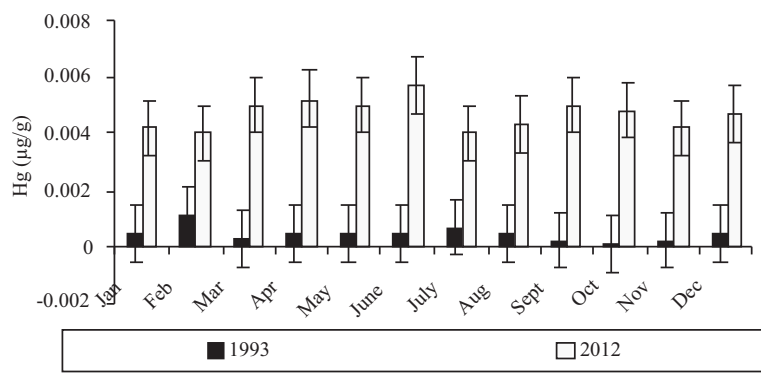

Fig. 5. $\mathrm{Hg}$ concentration in P. viridus in two different periods.

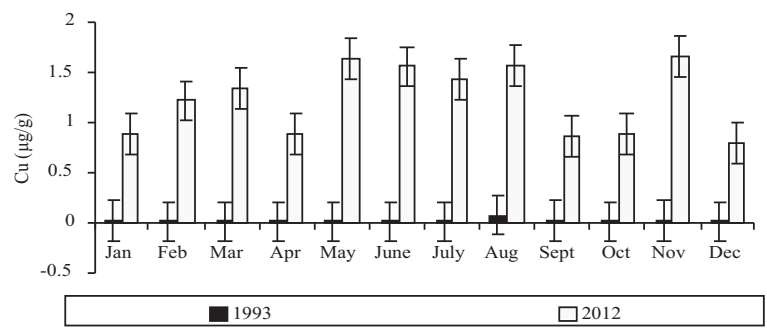

Fig. 7. $\mathrm{Cu}$ concentration in $P$. viridus in two different periods. 


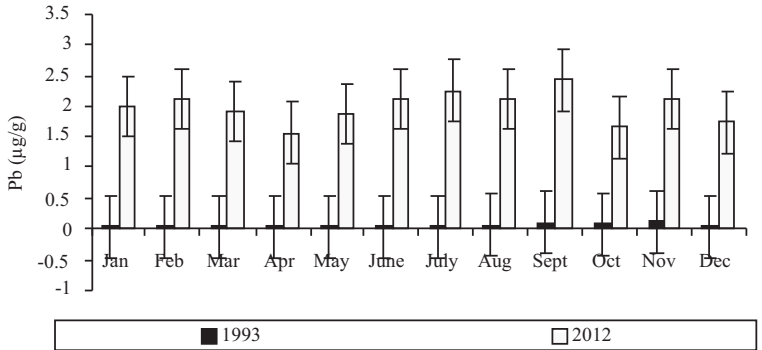

Fig. 8. $\mathrm{Pb}$ concentration in $P$. viridus in two different periods.

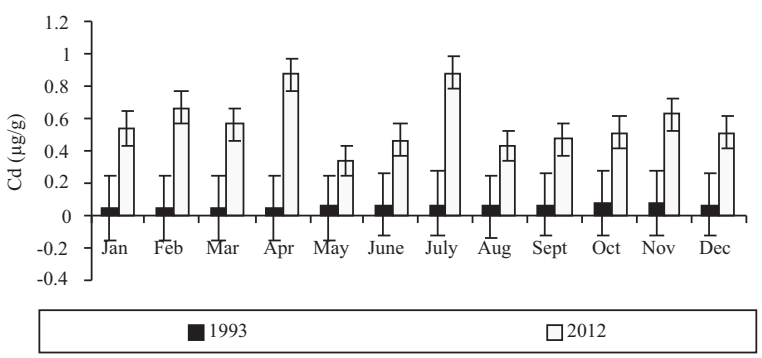

Fig. 10. Cd concentration in $P$. viridus in two different periods.

indicating the tendency of organism in accumulating lower concentration of $\mathrm{Hg}$ in soft tissue. In a study conducted by Usero et al. (2005), Hg showed the lowest values among all the metals studied on heavy metal concentrations in molluscs from the Atlantic coast of southern Spain.

The data generated from this study, showed that the concentrations of metals in the mussels collected from the Paradise Point are increasing with time. Obviously, the present investigation recorded highest concentrations of heavy metals in the year 2012 when compared to the year 1993. On a normal basis, it was expected that the levels of the heavy metals in 2012 would have drop drastically after the first detection levels of the heavy metals in the year 1993 but the reverse was the case. This is an indication that the Paradise Point of the Karachi coastal areas is subjected to intense industrial and anthropogenic activities and that coastal population encroachment and sewerage system plays an important role in the increase of metal concentration levels. Besides, there is an accelerating accumulation of toxic metals and gases in atmosphere, irrigation water and agricultural soils while the industrial estates of Karachi are discharging large quantities of effluents of organic matter, heavy metals, oil, greases, liquid and solid wastes into Malir and Lyari rivers, which are causing serious environmental

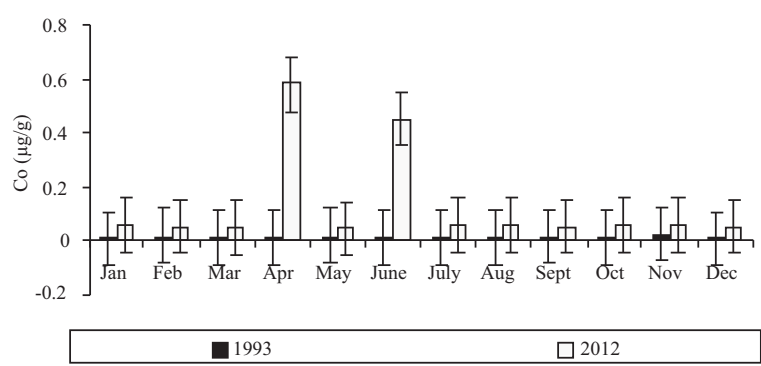

Fig. 9. Co concentration in P. viridus in two different periods.

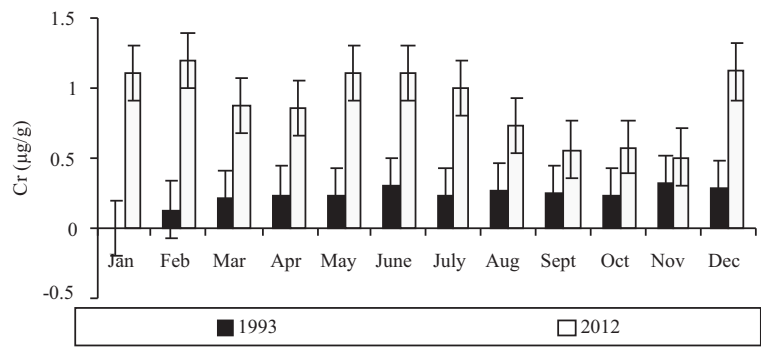

Fig. 11. Cr concentration in P. viridus in two different periods.

degradation (Khattak et al., 2012) to various ecosystems of the city.

\section{Conclusion}

The concentrations of these heavy metals were within the maximum permissible level (MPL) and should result in no acute toxicities of the metals since they were lower than the permissible limits for human consumption. In addition, these metal concentrations were also considered to be low when compared with regional data based on $P$. viridis as a biomonitoring agent. However, the data generated from this study, showed that the concentrations of metals in the mussels collected from the Paradise Point are increasing with time. Obviously, the higher accumulations of metals were found mostly in the samples collected at the Paradise Point of Karachi coast in the year 2012 when compared with the samples collected in the year 1993 at the same sampled site. This is an indication that the area under study showed signs of being exposed to significant levels of heavy metal pollution due to direct discharge of industrial and domestic wastes along the coast. In view of this, continued monitoring of heavy metals from Paradise Point of Karachi coast should be undertaken to avoid reduction in the valuable export of bivalves and shrimps as well as the reduction of marine life in the coastal waters. 
The most important large industries in Karachi involve metal and non-metal manufacturing textiles, tobacco, food and beverages, chemicals, paints, rubber, paper and paper product, pharmaceutical and product of coals and oil that contributes approximately $99 \%$ of the total industrial pollution (Khan and Saleem, 1988; Haq, 1976) which resulted to a considerable trace metal contamination of the marine environment. Immediate measures to control the indiscriminate discharge of effluent and domestic sewage directly or indirectly in to the sea need to be addressed. In addition, regular monitoring programmes of marine pollution are essentially required and need to be well implemented. If this pollution persists, it can prove to be very detrimental in future. The use of green mussel ( $P$. viridis) as a suitable biomonitor for heavy metals concentration could be employ in programmes designed to identify, assess, control, and reduce pollution problems in the coast of Paradise Point of Karachi.

\section{References}

Ali, S., Begum, F., Hussain, S.A., Khan, A.S., Ali, H., Khan, T., Raza, G., Ali, K., Karim, R. 2014. Biomonitoring of heavy metals availability in the marine environment of Karachi, Pakistan, using oysters (Crassostrea sp.). International Journal of Biosciences, 4: 249-257.

Ansari, T.P., Kazi, T.G., Kazi, G.H. 2001. Chemical composition of sewage sludge of domestic and industrial areas of Hyderabad. Pakistan Journal of Analytical Chemistry, 2: 29-31.

Blackmore, G., Wang, W-X. 2003. Inter population differences in $\mathrm{Cd}, \mathrm{Cr}$, Se and $\mathrm{Zn}$ accumulation by the green mussel $P$. viridis acclimated at different salinities. Aquatic Toxicology, 62: 205-218.

Denton, G.R.W., Burdon-Jones, C. 1986. Trace metal in algae from the Great Barrier Reef. Marine Pollution Bulletin, 17: 98-107.

FDA, 2001. Fish and Fisheries Products: Hazards and Controls Guidance. $3^{\text {rd }}$ edition, Department of Health and Human Services, USA.

Haq, S.M. 1976. Over view on pollution in coastal environment of Pakistan and its possible implication for the marine ecosystem. In: Proceedings of International Symposium in Marine Pollution Research. P. S. Meyers (ed), pp. 33-53, Baton Rouge Louisiana State University, Gulf Breeze, Florida, USA.

Hasnie, F.R., Qureshi, N.A. 2002. Quantification of pollution load in wastewater channels of village Rehri draining in to Korangi creek. Pakistan Steel
Research Journal, 3: 47-54.

Horne, R.A. 1969. Marine Chemistry. 568 pp., John Wiley and Sons, Inc., USA.

Kamaruzzaman, B.Y., Mohd Zahir, M.S., Akbar J.B., Jalal, K.C.A., Shahbudin, S., Al-Barwani, S.M., Goddard, M.S. 2011. Bioaccumulation of some metals by green mussel $P$. viridis (Linnaeus 1758) from Pekan, Pahang, Malaysia. International Journal of Biological Chemistry, 5: 54-60.

Khan, S.H., Saleem, M. 1988. A preliminary study of pollution in Karachi harbour. In: Proceedings of Marine Science of the Arabian Sea. M. F. Thompson and N. M. Tirmizi (eds.), pp. 539-548, American Institute of Biological Sciences, Washington D.C., USA.

Khattak, M.I., Khattak, M.I., Mohibullah, M. 2012. Study of heavy metal pollution in mangrove sediments reference to marine environment along the coastal areas of Pakistan. Pakistan Journal of Botany, 44: 373-378.

Krishnakumar, P.K., Bhat, G.S., Vaidya, N.G., Pillai, V.K. 1998. Heavy metal distribution in the coastal waters of Karnataka, west coast of India. Indian Journal of Marine Science, 27: 201-205.

Krishnakumar, P.K., Casillas, E., Varanasi, U. 1995. Effects of environmental contaminants on the health of Mytilus edulis from Puget Sound, Washington, USA. II. Cytochemical detection of subcellular changes in the digestive cells. Marine Biology, 124: 251-259.

Krishnakumar, P.K., Casillas, E., Varanasi, U. 1994. Effects of environmental contaminants on the health of Mytilus edulis from Puget Sound, Washington, USA. I. Cytochemical measures of lysosomal responses in the digestive cells using automatic image analysis. Marine Ecology Progress Series, 106: $249-261$.

Leah, R.T., Evans, S.J., Johnson, M.S. 1982. Mercury in flounder (Platichthys flesus L.) from estuaries and coastal waters of the northeast Irish Sea. Environmental Pollution, 75: 317-322.

Li, Y., Yu, Z., Song, X., Mu, Q. 2006. Trace metal concentrations in suspended particles, sediments and clams (Ruditapes philippinarum) from Jiaozhou bay of China. Environmental Monitoring and Assessment, 121: 491-501.

MFR, 1985. Malaysian Law on Food and Drugs. Malaysia Law Publisher, Kuala, Lumpur, Malaysia.

Moraes, L.A.P., Lenzi, E., Luchese, E.B. 1997. Mercury in two fish species from the Parana river floodplain, 
Parana, Brazil. Environmental Pollution, 98: 123127.

Ololade, I.A., Lajide, L., Amoo, I.A., Oladoja, N.A. 2008. Investigation of heavy metals contamination of edible marine seafood. African Journal of Pure and Applied Chemistry, 2: 121-131.

Qari, R., Ajiboye, O., Manzoor, R., Afridi, A. 2015. Seasonal variation in occurrence of heavy metals in $P$. viridis from Manora channel of Karachi, Arabian Sea. International Journal of Marine Science, 5: $1-13$.

Qari, R., Siddiqui, S.A. 2008. Heavy metal pollution in coastal seawater of Nathia gali, Karachi (Pakistan). Journal of Environmental Research and Development, 3: 9-19.

Qari, R., Siddiqui, S.A. 2004. Heavy metal levels in coastal seawater of Paradise point, Karachi. SEGMITE: A Journal of Resources, Industrial and Environmental Geology, 1: 21-25.

Riley, J.P., Skirrow, G. 1975. Chemical Oceanography. Academic Press, vol. 1, 606 pp., London, UK.

Rizvi, S.H.N., Saleem, M., Baquer, J. 1988. Steel mill effluents: Influence on the Bakran Creek Environment. In: Proceedings of Marine Science of the Arabian Sea. M. F. Thompson and N. M. Tirmizi, (eds.), pp. 549-569, American Institutes of Biological Sciences, Washington, DC, USA.

Roesijadi, G. 1980. The significance of low molecular weight, metallothionein-like proteins in marine invertebrates: current status. Marine Environmental Research, 4: 167-179.

Sankaranarayanan, V.N., Purushan, K.S., Rao, T.S.S. 1976. Concentration of some of the heavy metals in the oyster Crassostrea madrasensis from the Cochin region. Indian Journal of Marine Sciences, 7: 130-131.
Sasikumar, G., Krishnakumar, P.K., Bhat, G.S. 2006. Monitoring trace metal contaminants in green mussel, $P$. viridis from the coastal waters of Karnataka, southwest coast of India. Archives Environmental Contamination and Toxicology, 51: 206-214.

Shin, P.K.S., Yau, F.N., Chow, S.H., Tai, K.K., Cheung, S.G. 2002. Response of the green lipped mussel (Mytilus viridis L.) to suspended solids. Marine Pollution Bulletin, 1: 157-162.

Siddique, A., Mumtaz, M., Zaigham, N.A., Mallick, K.A., Saied, S., Zahir, E., Khwaja, H.A. 2009. Heavy metal toxicity levels in the coastal sediments of the Arabian Sea along the urban Karachi (Pakistan) region. Marine Pollution Bulletin, 58: 1406-1419.

Usero, J., Morillo, J., Gracia, I. 2005. Heavy metal concentrations in molluscs from the Atlantic coast of southern Spain. Chemosphere, 59: 1175-1181.

WHO, 1982. Toxicological Evaluation of Certain Food Additives. 106 pp., World Health Organization, Geneva, Switzerland.

Yap, C.K., Ismail, A., Edward, F.B., Tan, S.G., Siraj, S.S. 2006. Use of different soft tissues of Perna viridis as biomonitors of bioavailability and contamination by heavy metals $(\mathrm{Cd}, \mathrm{Cu}, \mathrm{Fe}, \mathrm{Pb}, \mathrm{Ni}$ and $\mathrm{Zn}$ ) in a semi enclosed intertidal water of the Johore straits. Toxicological \& Environmental Chemistry, 88: 683-695.

Yap, C.K., Ismail, A., Tan, S.G., Ismail, A.R. 2007. The distribution of the heavy metals $(\mathrm{Cu}, \mathrm{Pb}$ and $\mathrm{Zn})$ in the soft and hard tissues of the green-lipped mussel P. viridis (L.) collected from Pasir Panjang, Peninsular, Malaysia. Pertanika Journal of Tropical Agricultural Science, 30: 1-10.

Zhou, H.Y., Wong, M.H. 2000. Mercury accumulation in freshwater fish: emphasis on the dietary influence. Water Research, 34: 4234-4242. 